\title{
Social media as a route to developing the agrifood sector in Spain
}

\author{
Adoración Mozas-Moral* Enrique Bernal-Jurado**, \\ Domingo Fernández-Uclés*, Miguel Jesús Medina-Viruel***
}

DOI: $10.30682 / \mathrm{nm} 1802 \mathrm{~h}$

JEL codes: L10, L81, Q57

\begin{abstract}
The Internet has undoubtedly had an impact on society and brought about considerable changes in the world economy. Social media are prominent among the applications hosted by the Internet. To organisations that make use of them, they present a series of challenges and opportunities that can lead to enhanced business performance and local and regional development. Given the foregoing, the Delphi method was used to assess the impact of social media on product marketing in the Spanish olive oil sector. The findings of this study, based on expert opinion, point to the potential of social media, which in turn makes it necessary to plan for their use.
\end{abstract}

Keywords: Olive oil, ICT, Social media, Spain.

\section{Introduction}

One of the great challenges that southern European edible oil sector SMEs (small and medium enterprises) face is how to retain most of the added value generated through the sale of their products. The Spanish olive oil sector is an example of this: Spain is the largest olive oil producer in the world, with $40 \%$ of the world output and $50 \%$ of the European Union output (MAGRAMA, 2013), making this a key strategic sector for the country's economy and an essential component of sustainable development in the rural world. Nevertheless, product marketing continues to be one of the outstanding challenges facing this sector (Mozas et al., 2007; Fernández et al., 2016).
Using the Internet for commercial purposes could provide answers to these problems (López et al., 2014). Given that one of the characteristics of the market in the early $21^{\text {st }}$-century is the globalisation of production and sales, a basic requirement in order to trade with any guarantee of success is to use information and communication technology (ICT) (Medina et al., 2016; Mozas et al., 2016a). Information and communication technologies have changed the rules of competition (Laudon and Laudon, 2009) by bringing down organisational costs throughout the value chain and speeding up searches for buyers and sellers and, in general, for information associated with the commercial activity (Chen and Seshadri, 2007).

\footnotetext{
* Department of Business Organization, Marketing and Sociology, University of Jaén (Spain).

** Department of Economics, University of Jaén (Spain).

*** Department of Statistics, Econometrics, Operational Research, Business Organization and Applied Economics, University of Cordoba (Spain).

Corresponding author: dfucles@ujaen.es.
} 
In the case of SMEs (which applies to most olive oil companies), ICT is particularly important in enabling them to take full advantage of the opportunities offered by the new technological paradigm (Sadowski et al., 2002). The limited financial and human resources of these companies restrict their access to international markets, so ICT tools are essential for minimising the effects of their structural weaknesses and facilitating their internationalisation (Rasheed, 2005). This is because ICT lessens the importance of geographical distance when entering foreign markets and accessing customers and suppliers (Stansfields and Grant, 2003).

In particular, social media and online social networks are the main exponents of the new panorama. These platforms provide support for the social relations formed within organisations and externally, and lead to multiple business improvements at little cost (Gunelius, 2011). Their main advantages include: improvements in organisational communication, consumer trust (Lai et al., 2011) and commercial position (Wei et al., 2013). This should encourage organisations to take advantage of these tools as a marketing strategy, to boost collective learning and to improve their management, coordination and exchange of knowledge (Elghannam et al., 2017).

Despite the potential of the social media for marketing agrifood products online, few studies have examined the relations between the two (MAGRAMA, 2013). Given this situation, the overall aim of this research was to cast light on the prospects for olive oil organisations in the social media and elucidate the usefulness of these tools for solving the main problems facing this sector, particularly in relation to marketing and sales. For this purpose, an empirical study was carried out during the first half of 2015 , using a prospective analysis based on the Delphi method. This method was considered appropriate for addressing the main aim of this study: to conduct a prospective analysis on the use of online social networks by olive oil organisations and to discover whether or not they are useful for solving this sector's commercial problems.

\section{Conceptual Framework}

ICT is considered a factor of great importance for rural development (Romero and Cànoves, 2005), offering a wide range of opportunities for economic and social improvements in agricultural regions, e.g. in relation to rural tourism (Castells, 1997). Following this approach, Perkins and Witt (1961) were already pointing to the importance of linking agriculture with its commercial aspect and associating it with technological innovations (Castro and Rajadel, 2015), which are indispensable for the farming sector and a decisive factor for competitiveness (Cáceres, 2002). They are also associated with productivity, considered a critical factor for the prosperity and enrichment of the rural population, particularly for those with very low incomes (Shejtman and Berdegué, 2004). According to Castro and Rajadel (2015), technology and innovation support, direct and stimulate local development, encouraging business productivity, competitiveness, and social, economic and intellectual development.

The use of ICTs in the Spanish olive oil sector could be a spur to economic and social development in Spain (Medina et al., 2016). It should be remembered that Spain - particularly Andalusia, one of its least developed regions - is one of the top olive oil producing areas in the world. Despite its size, this sector has traditionally faced considerable problems on the commercial side (Mozas et al., 2015). These companies mostly sell their product in bulk, ceding a high proportion of the olive oil value chain to refiners and bottling plants as well as to the distributors (MAGRAMA, 2012). It is estimated that approximately $80 \%$ to $90 \%$ of their output is sold to refiners and bottlers, who reap the added value generated by this activity (Parras et al., 2013). The latter bottle the product and negotiate with the distribution sector and food-processing companies (confectionery, snacks, preserves, etc.). As a result of its low involvement in selling its products, the Spanish olive oil sector has remained in a weak position, in comparison with its potential, on both the home and foreign markets (Moral et al., 2014; Medina et al., 2016). 
Along the same lines, Fransi et al. (2016) emphasised the outstanding potential of the Internet for olive oil sector companies, where cooperative and social relations predominate. Precisely these characteristics, as well as the structure of the olive oil sector itself, which is heavily weighted towards the social economy ${ }^{1}$, give rise to many resemblances with what is known as the "social web" (Mozas and Bernal, 2012). For this reason, olive oil companies should not allow the opportunity offered by this new social and technological phenomenon to slip through their grasp, particularly if their output includes organic products (Vega et al., 2011). Social media may be a factor to take into account for rural development in the olive oil sector (Mozas et al., 2015), not only because of their technological component but also as a system of personal and inter-organisational interactions.

Authors such as Moral et al. (2014) and Fransi et al. (2016) have shown how these technologies have led to major commercial progress in olive oil sector companies, which suffer from a passive attitude towards marketing, leading to ICT being considered an essential pillar of improvement in the agrifood sector (Medina et al., 2016). Given this situation, such authors give a glimpse of the major role that new ICT tools such as the social media can play in the olive oil sector, as a route to commercial and regional progress. However, according to Cáceres (2002), the adoption of new technologies needs to be planned and companies must carefully monitor their adoption. In addition, they must possess sufficient absorption capacity to implement and use them efficiently. This statement can be extended to the social media, as their successful introduction hinges on three factors: attentive adoption, community building and absorption capacity (Culnan et al., 2010). Social media are free of charge and although computer support is a requirement for accessing them, this is relatively inexpensive and affordable for the population as a whole (House et al., 2015), although resources need to be assigned to them if they are to be used efficiently (Mozas et al., 2016b).

In short, the social, communicative and interactive characteristics of online social networks highlight the many benefits they bring to businesses, boosting their entrepreneurial, commercial and relational facets (Rita and Sunny, 2012). As a result, these tools are a mainstay for improving the organisational and commercial activity of olive oil companies (Mozas et al., 2016b). Specifically, it should be pointed out that by reducing the organisation's operating costs, particularly in relation to the market (House et al., 2015), ICT has helped to cut transaction costs substantially, encouraging an efficient administration of corporate resources (Chen and Seshadri, 2007).

\section{Material and Methods}

Delphi prospective analysis is a method that aims to provide information on situations that require forecasting and human judgement, when the scarcity of data and of a theoretical background make it impossible to employ statistical methods (Goldfisher, 1992; Rowe and Wright, 1999). Such situations make it necessary to turn to experts who can cast light on the subject of study thanks to their knowledge and experience. This technique is designed as a group communication process that prevails over individual judgements and seeks to reach consensus among experts regarding a particular problem (Linstone and Turoff, 1975). The group of experts whose opinion was sought comprised academics and olive oil sector professionals with links to the field of the social media.

The principal characteristics of this method, and a sine qua non for its success, are (Rowe and Wright, 1999; Landeta, 2006; Hsu and Sandford, 2007): anonymity, in order to ensure the originality and variety of the judgements proffered; iteration, which helps to elicit more substantial data; and controlled feedback, an essential char-

\footnotetext{
${ }^{1}$ Oil mills that take a social economy enterprise form - mainly cooperatives, agricultural processing companies (sociedades agrarias de transformación) and labour companies (sociedades laborales) - produce over $70 \%$ of the olive oil in Spain (Mozas et al., 2015). Consequently, to speak of olives is to speak of social economy enterprises (Fernández et al., 2016).
} 
acteristic to encourage the experts to reconsider their opinion and reach a consensus. One of its main advantages is its predictive and exploratory character, which is ideal in situations of uncertainty (Linstone and Turoff, 1975; Goldfisher, 1992). Research has demonstrated the reliability, efficacy and currency of this method (Rowe and Wright, 1999; Landeta, 2006).

The non-existence of statistical data on the subject, the scarcity of references on this relation in the agrifood sector, the requirement of a forecasting exercise and the confluence of subjective aspects that in many cases demand reflection and group analysis were factors that warranted using this method. Other similar research with the same background has also employed the Delphi method. For instance, it has been employed in studies of the agrifood sector (Frewer et al., 2011; Campos et al., 2012; Kline et al., 2016) and of social media websites (Axinia, 2011; Linke and Zerfass, 2012). Research that has used this method to highlight the need and importance of investing in $\mathrm{R}+\mathrm{D}+\mathrm{I}$ in the olive oil sector was also found, including Sanz et al. (2011) and Sayadi et al. (2012).

\subsection{Specific Research Aims}

In order to cast light on the impact of greater social media use in the olive oil sector in Spain, as well as to validate its value and utility for organisations in this sector, the following research questions were formulated:

RQ1. Are social media a factor that generates value for olive oil companies?

RQ2. To what extent will the olive oil sector use social media in the near future?

RQ3. In the olive oil sector, which business functions will benefit most from using social media?

RQ4. What factors encourage or curb social media penetration of the business fabric in the olive oil sector?

RQ5. What advantages and disadvantages would greater social media use bring to the business fabric of the olive oil sector?

RQ6. Are social media particularly useful in the case of organic olive oil?

\subsection{Research Process}

The experts were selected by contacting a heterogeneous group of academics and sector professionals who work in different provinces of Spain (Table 1), in order to draw on different points of view and sensitivities (Von der Gracht, 2012). The optimum size for the expert panel, considering the characteristics and complexity of the subject, was considered to be between 15 and 20 persons. This range is considered sufficiently large and methodologically reliable by a number of authors (Malla and Zabala, 1978; Okoli and Pawlowski, 2004; Landeta, 2006). The questionnaire was therefore sent to 22 experts, of whom 20 finally participated in both rounds. They all had a university education, considerable empirical experience and an advanced knowledge of social media due to their educational background and area of work. In addition, all the experts had links to the agrifood sector, particularly in olive oil, and most of them had a reputation for research focusing on this product.

The questionnaire and the options included were drawn up with reference to the existing literature, taking into account the typical strengths, weaknesses, opportunities and threats (SWOT) in this sector (Ciruela and Cuadrado, 2012). The result was a compact, structured, self-completion questionnaire that would be quick and easy to complete. This initial questionnaire was mostly composed of Likert scale questions, the method of measurement overwhelmingly used in Delphi studies (Linstone and Turoff, 1975). It also included open qualitative questions in order to elicit the freely-expressed opinion of the experts, which would be very useful for interpreting the results. For the second round, personalised

Table 1 - Expert panel data.

\begin{tabular}{|l|c|c|c|c|c|c|}
\hline \multirow{3}{*}{ Location } & \multicolumn{2}{|c|}{$\begin{array}{c}\text { Aca- } \\
\text { demics }\end{array}$} & \multicolumn{2}{c|}{$\begin{array}{c}\text { Sector pro- } \\
\text { fessionals }\end{array}$} & \multicolumn{2}{|c|}{ Total } \\
\cline { 2 - 7 } & No. & $\%$ & No. & $\%$ & No. & $\%$ \\
\hline Rest of Spain & 8 & 80 & 4 & 40 & 12 & 60 \\
\hline Andalusia & 2 & 20 & 6 & 60 & 8 & 40 \\
\hline Total & 10 & 50 & 10 & 50 & 20 & 100 \\
\hline
\end{tabular}

Source: own compilation. 
questionnaires were designed; they included the expert's previous response and statistical indicators on the group response, to provide feedback (Landeta, 2006; Rowe and Wright, 1999).

The number of rounds was pre-set at two, a number of iterations that is recommended and considered sufficient by most of the authors who have addressed this method (Luna et al., 2006; Mohedano, 2013). However, if the results required a third round this possibility was left open, as it would be useful for obtaining more precise results (Juliá and Polo, 2006). In the event, the third round proved not to be necessary as a high degree of consensus and/or stability had already been achieved.

For this purpose, the level of consensus was established in advance in accordance with the following criteria: for nominal questions, the degree of agreement among the experts was set at a minimum of $90 \%$. For the Likert-type questions, the interquartile range (IQR) was set at 1 or less for four- or five-point scales (Von der Gracht, 2012). For questions comprising different items, Kendall's coefficient of concordance $(\mathrm{W})^{2}$ was used as a holistic verification of the degree of agreement on the order of preference for the items (Escobar and Cuervo, 2008). To infer whether this concordance was significant for the ranges compared, the coefficient was converted into a Chi squared value . $^{3}$

In addition, Spearman's rank correlation coefficient $\left(\mathrm{r}_{\mathrm{s}}\right)$ was used as an indicator of stability, with a value close to 1 indicating high stability (Badii et al., 2014).

\section{Results}

This section only reports the results on which the two rounds of consultation with the experts obtained consensus and/or stability according to the premises stated in the Methods.

The first approach to the field of study, which attempted to obtain an answer to the first research question (RQ1), found that most of the experts stated that these technological social tools were useful for increasing the consumers' appreciation of olive oil (Table 2).

As can be seen in Table 2, most (95\%) of the experts consulted considered the presence of olive oil in the social media to be beneficial. They also agreed in pointing to Facebook and Twitter as the most suitable platforms for olive oil from a business point of view. In addition, although without consensus, $45 \%$ of the experts mentioned LinkedIn, and other online social networking platforms were also cited, particularly those related with picture sharing (Instagram, Flickr and Pinterest).

The results regarding the degree of penetration of these tools (RQ2) and the business functions that benefit most from them (RQ3) are shown in Table 3.

The consensus reached in the second round was that in the near future, the penetration of social media use in olive oil sector businesses will be high. As well as the consensus criterion, based on the statistical criterion (IQR $\leq 1)$, a high level of stability was also found $\left(\mathrm{r}_{\mathrm{s}} 0.99\right)$. As regards the business functions that will benefit most from greater use of social media, the consensus pointed to marketing (unanimously), customer care and organisational communication.

Turning now to the factors that boost and curb social media penetration of the business fabric in the olive oil sector (RQ4), Table 4 shows the items that achieved consensus and stability in the two rounds of responses from the panel.

\footnotetext{
2 This coefficient (Kendall's W) ranges from 0 to 1 , where 0 is the total absence of agreement and 1 is perfect agreement on the ranking order: It was calculated as follows:$$
w=\frac{12 \sum D^{2}}{m^{2} n\left(n^{2}-1\right)}
$$$$
\text { where } \mathrm{m} \text { is the number of experts, } \mathrm{n} \text { the number of items and } D=\sum R-\left(\sum \frac{R}{n}\right) \text {, where } \mathrm{R} \text { is the total rank. }
$$

${ }^{3}$ If $X_{r}^{2}<X^{2}(: n-1)$ then the null hypothesis $\left(\mathrm{H}_{0}\right)$ of non-agreement is accepted, and vice versa. The result obtained was compared with the table of chi-squared values with $n$-1 degrees of freedom and a significance level $(\alpha)$ of 0.01 $\left(X^{2}(: n-1)\right)$. For this, the following equation was calculated: $X_{r}^{2}=m(n-1) w$.
} 
Table 2 - Consensus results for RQ1.

\begin{tabular}{|l|r|r|}
\hline \multicolumn{1}{|c|}{ QUESTION } & \\
\hline $\begin{array}{l}\text { Do you consider that the presence of olive oil in the } \\
\text { social media increases the consumers' appreciation } \\
\text { of olive oil? }\end{array}$ & & \\
\hline
\end{tabular}

Source: own compilation.

Table 3 - Consensus results for RQ2 and RQ3.

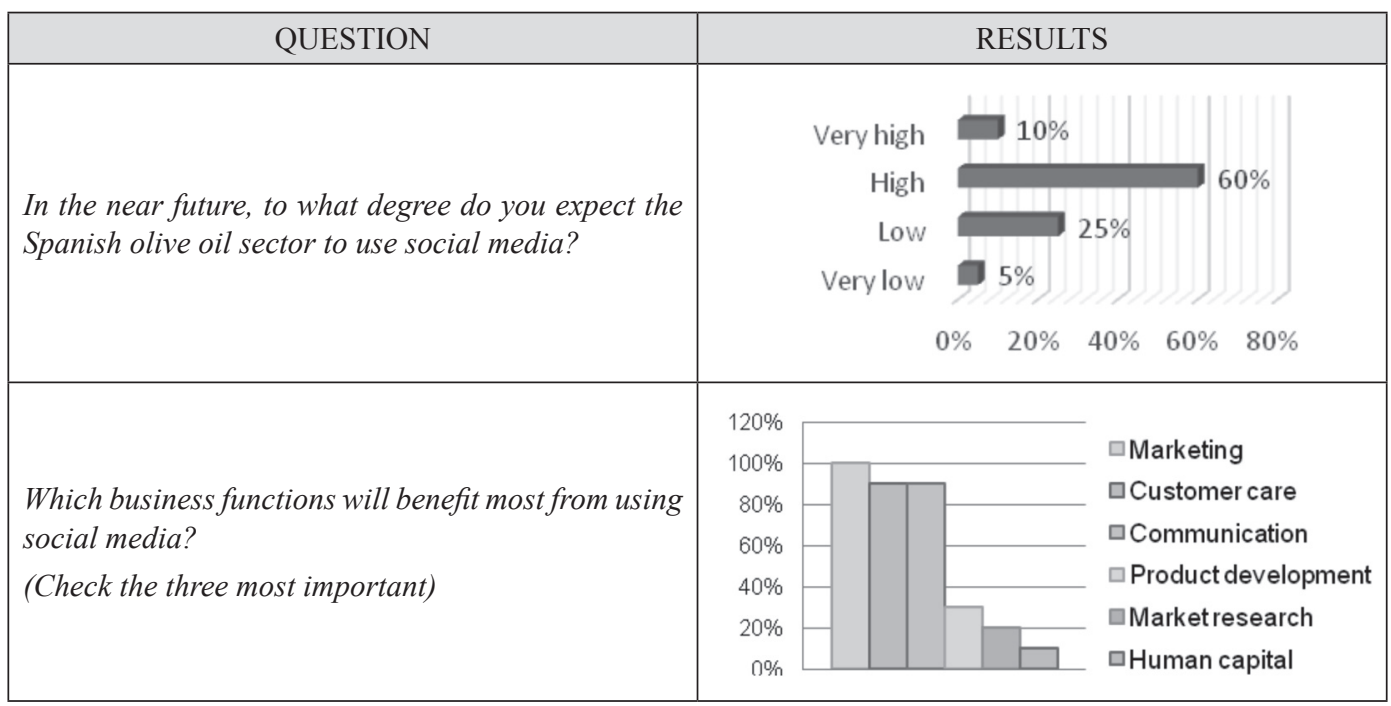

Source: own compilation.

After the second round, Kendall's W was calculated to check whether the agreement on the ranking of the factors (both drivers and inhibitors) was statistically significant. These calculations found agreement on the order of the items in both cases.

Concerning the possible advantages and disadvantages of greater social media use in the olive oil sector (RQ5), consensus and stability were obtained for the following items (Table 5).
As in the previous question, the level of group agreement between the items was calculated. Strong agreement was found on the order of the possible advantages. Agreement on the order of the disadvantages was weaker, although still statistically significant.

The last question the experts were asked referred to organic products in particular, in view of the boom that this type of agriculture is experiencing. Moreover, online social networks 
Table 4 - Consensus results for RQ4.

\begin{tabular}{|l|c|c|c|}
\hline \multicolumn{1}{|c|}{ QUESTION } & \multicolumn{2}{c|}{ RESULTS } \\
\multicolumn{1}{|c|}{$\begin{array}{c}\text { Factors driving greater social media } \\
\text { use in the olive oil sector }\end{array}$} & Group assessment & IQR & $r_{s}$ \\
\hline $\begin{array}{l}\text { - Greater training in social media tools } \\
\text { - Fear of a fall in sales due to a lack of presence in the social } \\
\text { media }\end{array}$ & Very important & 1 & $\approx 1$ \\
- Rise in perceived usefulness & Important & 1 & $\approx 1$ \\
- External pressure & Important & 0 & $\approx 1$ \\
- Improvements in social media security and privacy policies & Important & 0 & $\approx 1$ \\
- Public action plan and assistance to encourage the use of & Not very important & 1 & 1 \\
social media & & & \\
\hline \multicolumn{1}{|c|}{ Factors inhibiting greater social media } & Group assessment & $I Q R$ & $r_{s}$ \\
\hline - Ignorance of the potential of these tools & Very important & 1 & $\approx 1$ \\
- Lack of interest and of advice & Very important & 1 & $\approx 1$ \\
- Lack of financial resources & Not very important & 1 & $\approx 1$ \\
- Technological limitations & Not very important & 1 & $\approx 1$ \\
- Product unsuitable for promotion in social media & Not at all important & 1 & $\approx 1$ \\
\hline
\end{tabular}

Source: own compilation.

Table 5 - Consensus results for RQ5.

\begin{tabular}{|c|c|c|c|}
\hline QUESTION & \multicolumn{3}{|c|}{ RESULTS } \\
\hline Advantages of greater social media use in the olive oil sector & Group assessment & $I Q R$ & $r_{s}$ \\
\hline - Higher market profile for olive oil & Very probable & 0 & $\approx 1$ \\
\hline $\begin{array}{l}\text { - More information reaching users, so better knowledge and } \\
\text { identification of the different types of olive oil and their } \\
\text { characteristics }\end{array}$ & Very probable & 1 & $\approx 1$ \\
\hline $\begin{array}{l}\text { - Greater communication and spread of olive oil culture outside } \\
\text { the Mediterranean area }\end{array}$ & Very probable & 1 & $\approx 1$ \\
\hline $\begin{array}{l}\text { - Greater involvement of olive oil producers in consumer } \\
\text { markets }\end{array}$ & Probable & 1 & $\approx 1$ \\
\hline $\begin{array}{l}\text { - Within the olive oil sector, greater awareness of its own } \\
\text { deficiencies and limitations }\end{array}$ & Not very probable & 1 & $\approx 1$ \\
\hline Disadvantages of greater social media use in the olive oil sector & Group assessment & $I Q R$ & $r_{s}$ \\
\hline - More competitive pressure & Probable & 0,25 & 1 \\
\hline $\begin{array}{l}\text { - Democratisation of the organisation (increased stakeholder } \\
\text { power) }\end{array}$ & Not very probable & 0,25 & $\approx 1$ \\
\hline - Likelihood of damaging the brand or corporate image & Not very probable & 1 & $\approx 1$ \\
\hline - Technical problems in introducing these tools & Not very probable & 1 & $\approx 1$ \\
\hline - Problems with privacy and information leaks & Not at all probable & 1 & 1 \\
\hline
\end{tabular}

Source: own compilation. 
Table 6 - Questions referring to organic products.

\begin{tabular}{|c|c|c|c|}
\hline QUESTION & \multicolumn{3}{|c|}{ RESULTS } \\
\hline $\begin{array}{l}\text { Questions to ascertain the possible effects of social media } \\
\text { for organic products }\end{array}$ & Group assessment & $I Q R$ & $r_{s}$ \\
\hline $\begin{array}{l}\text { Social media are an effective tool for publicising and informing } \\
\text { about the attributes of extra virgin organic olive oil }\end{array}$ & Agree totally & 0 & $\approx 1$ \\
\hline $\begin{array}{l}\text { Social media are the most suitable platform for boosting con- } \\
\text { sumption of extra virgin organic olive oil }\end{array}$ & Agree totally & 0 & $\approx 1$ \\
\hline $\begin{array}{l}\text { Olive oil companies with organic products will use social media } \\
\text { more than those with non-organic ones }\end{array}$ & Agree & 1 & $\approx 1$ \\
\hline
\end{tabular}

Source: own compilation.

are particularly useful for products of this type (Mozas et al., 2016b), which have historically been overlooked or had little presence in traditional sales channels, as some authors argue (Wei et al., 2013). The consensus results for this question are shown in Table 6.

The above table shows that without a doubt, most of the experts agreed that social media are beneficial for olive oil with the attribute 'organic', which further increases the usefulness of these tools for the olive oil sector.

\section{Discussion}

The Delphi analysis showed the usefulness and importance of online social networking platforms for responding to the commercial problems that the Spanish olive oil sector has traditionally faced.

Firstly, it was clear that there was considerable consensus on the social media's capacity to increase the consumers' appreciation of olive oil. The sector is not unaware of this opportunity, so olive oil companies were expected to develop a prominent presence in these social media. Another salient result is that the functions that were expected to benefit included marketing, customer care and communication, which would imply that the olive oil sector is on its way to taking advantage of the potential of the social media for improving organisational communication, consumer trust and the commercial position of the companies. This evidence has been studied, in other areas, by Lai et al. (2011) and Wei et al. (2013). As noted by Fernández et al. (2016), adoption and efficient use of social media could be a clear driver of development in the olive oil sector. The advantages associated with these tools could solve the commercial difficulties of olive oil producers, especially those faced by cooperatives, owing to the characteristics of this type of company.

Regarding the factors that boost or curb social media penetration of the business fabric of the olive oil sector, the level of information on the social media within this sector is a fundamental factor for their use. From this point of view, it is considered that a lack of interest fed by misinformation explains the widespread lack of knowledge about the potential of the social media, leading to limited use of them (Mozas et al., 2016b). Moreover, the companies that make up this sector are SMEs with limited financial and human resources. The characteristics of this type of organizations hinder the acquisition of knowledge about the potential of these applications and identification of their usefulness (Sandowski et al., 2002). For this reason, it is important not to base the use of these tools simply on their adoption: the olive oil companies must maintain a solid commitment to these media if they are to attain greater operational performance (Medina et al., 2016).

In turn, the experts considered that external pressure and the threat of a loss of clientele are the most important factors that encourage their use. As stated by Laudon and Laudon (2009), it is obvious that ICT is changing the rules of competition and is important if companies are to operate with any degree of success in today's 
globalised market, and organisations are trying to respond to this situation. Since many buyers now use social media as a reference tool, companies need to have a presence on them and adopt an active role in this regard, responding to the consumers' need and demand for information.

The findings of the present study have also served to confirm the advantages and disadvantages of a greater penetration of social media in the companies under study. For instance, financial or technological resources were not in themselves considered a major hindrance for introducing these tools, which require little investment and maintenance. Hence, as pointed out by authors such as Sadowski et al. (2002), ICT has the potential to minimise the effects of the structural weaknesses associated with SMEs (Rasheed, 2005). Also, although the literature considers privacy an important factor for the penetration of these tools, the experts did not believe this was likely to be a drawback for the sector under study.

However, the risk that the experts did consider probable following the introduction of these tools was greater competitive pressure. Nevertheless, it has also been asserted that this disadvantage could spur organisations to make improvements (Sadowski et al., 2002). The other side of the coin is that introducing these tools could generate multiple benefits. In particular, it was highlighted that social media websites have an important part to play in spreading knowledge and information on the culture surrounding olives and on olive oil and its characteristics. This result reflects the capacity of these tools for boosting collective learning and knowledge exchange (Lai et al., 2011). The experts also considered that social media use would probably bring greater producer involvement in final markets, a factor of great importance for this sector in view of its severe commercial problems.

In addition, and in agreement with Mozas et al. (2016b), the experts unanimously considered that social media can be an effective tool for marketing organic olive oil. It has also been shown that these tools can be one of the best ways to achieve this aim (Fransi et al., 2016). The findings of the present study show that social media provide a clear opportunity to develop the sec- tor, and organic producers are the operators that make most use of these online platforms and can obtain the greatest benefit from their use.

\section{Conclusions}

The overall objective of this study was to identify the prospects for olive oil companies in the social media and cast light on the usefulness of these platforms for solving the commercial problem that has traditionally held back the development of this sector. The findings of this study make it clear that these tools are useful for the development of the olive oil sector, always provided that sector organisations decide to make the commitment and devote part of their efforts to improving their presence in online social networks in order to take advantage of the full range of benefits they offer.

The present findings will help to make olive oil sector companies more aware of the potential of ICT and, in particular, of social media, and to prevent their sidelining themselves in this respect. This study has also brought to light factors that currently hinder the penetration of these new technologies among companies in this sector, particularly a lack of awareness of their potential. This finding should spur both public and private bodies to take timely steps to prevent the olive oil sector from lagging behind others.

One of the main limitations of this study is that it was confined to the olive oil sector, although the authors consider that the conclusions can be extrapolated to a large part of the agrifood sector, which, in general, presents similar underlying commercial problems. Another limitation is that it focuses on Spain. While this country occupies a privileged position as a major olive oil producer, it could be interesting to compare the situation in Spain with that in other producer countries.

In conclusion, the present study has contributed new knowledge to a little-studied subject: the relationship between the social media and commercial activity in the agrifood sector. The results of this exploratory study suggest a positive relationship between the two variables that warrants further investigation. Given the importance and topicality of these subjects, possible 
lines for future research could be empirical studies directly targeting the companies involved, to analyse aspects such as the level of penetration of these technologies, the intensity of their use and, fundamentally, the organisational, structural, etc. factors that are directly related with making more effective use of them. While searching for these relations, it would also be interesting to detect whether social media use has a positive effect on corporate productivity, using methods such as DEA for this purpose. Lastly, another interesting area could be direct analysis of these companies' social media activity in comparison with that of companies in other sectors.

\section{References}

Axinia E., 2011. What is the future of employer branding through social media? A Delphi study among academics. Twente: University of Twente.

Badii M.H., Guillen A., Serrato O. L., Garnica J.A. and Uanl S.N., 2014. Non-Parametric Correlation and Its Application in Scientific Research. International Journal of Good Conscience, 9(2): 31-40.

Cáceres D., 2002. Modernización tecnológica y desarrollo rural. Revista de Desarrollo Rural y Cooperativismo Agrario, 4.

Campos V., Apetrei A. and Chaves R., 2012. Delphi method applied to horticultural cooperatives. Management Decision, 50(7): 1266-1284.

Castells M., 1997. La era de la información: economía sociedad y cultura. La sociedad red. Madrid: Alianza Editorial.

Castro N.A. and Rajadel O.N., 2015. El desarrollo local, la gestión de gobierno y los sistemas de innovación. Revista Universidad y Sociedad, 7(1): 63-72.

Chen Y. and Seshadri S., 2007. Product development and pricing strategy for information goods under heterogeneous outside opportunities. Information Systems Research, 18(2): 150-172.

Ciruela A.M., and Cuadrado M., 2012. Análisis situacional del sector oleícola cooperativo andaluz. La búsqueda de la Competitividad. In: VII Congreso Internacional Rulescoop, Economía social: identidad, desafios y estrategias. Valencia-Castellón, España.

Culnan M.J., Mchugh P.J. and Zubillaga J.I., 2010. How large US companies can use Twitter and other social media to gain business value. MIS Quarterly Executive, 9(4): 243-259.
Delgado F.C., 1994. Planteamientos económicos del desarrollo rural: perspectiva histórica. Revista de Estudios Agrosociales, 169: 11-52.

Elghannam A., Escribano M. and Mesias F., 2017. Can social networks contribute to the development of short supply chains in the Spanish agri-food sector? New Medit, 16(1): 36-43.

Escobar J. and Cuervo A., 2008. Validez de contenido y juicio de expertos: una aproximación a su utilización. Avances en medición, 6: 27-36.

Fernández D., Bernal E., Mozas A., Medina M.J. and Moral E., 2015. El sector cooperativo oleícola y el uso de las TIC: un estudio comparativo respecto a otras formas jurídicas. REVESCO. Revista de Estudios Cooperativos, 120: 53-75.

Fernández D., Mozas A., Bernal E. and Medina M.J., 2016. Uso y eficiencia de la social media. Un análisis desde la economía social. CIRIEC-España, revista de economía pública, social y cooperativa, 88: 5-27.

Fransi E.C., Salla Y.M. and Adillón M.J.G., 2016. Factores determinantes del uso de internet en la comercialización del aceite de oliva. Análisis del sector en cataluña. REVESCO: Revista de estudios cooperativos, 121: 33-61.

Frewer L.J., Fischer A.R.H., Wentholt M.T.A., Marvin H.J.P., Ooms B.W., Coles D. and Rowe G., 2011. The use of Delphi methodology in agrifood policy development: some lessons learned. Technological Forecasting and Social Change, 78(9): 1514-1525.

Goldfisher K., 1992. A Modified Delphi: A Concept for New Product Forecasting. Journal of Business Forecasting: 10-11.

Gunelius S., 2011. 30 minutes social media marketing: step by step techniques to spread the words about your business. USA: McGraw-Hill.

House L.A., Jiang Y. and Salois M., 2015. Measures of Online Advertising Effectiveness for Market Penetration: The Case of Orange Juice Consumers. Canadian Journal of Agricultural Economics/Revue canadienne d'agroeconomie, 63(4): 435-448.

Hsu C.C. and Sandford B.A., 2007. The Delphi technique: making sense of consensus. Practical Assessment. Research and Evaluation, 12(10): 1-8.

Juliá J.F. and Polo F., 2006. La adaptación de las normas contables a las sociedades cooperativas con especial referencia a los fondos propios. Una aplicación del método Delphi. Revista Española de Financiación y Contabilidad, 35(132): 789-816.

Kay C., 2007. Enfoques sobre el desarrollo rural en América Latina y Europa desde mediados del siglo $\mathrm{XX}$. La enseñanza del desarrollo rural: enfoques y perspectivas: 49-111. 
Kline C.S., Joyner L.E., Kirchoff J.F., Crawford A., Jilcott Pitts S., Wall-Bassett E. and Dunning R., 2016. Gaps and barriers along the North Carolina agri-food value chain. British Food Journal, 118(2): 301-317.

Lai I.K.W., Tong V. and Lai D., 2011. Trust factors influencing the adoption of Internet-based interorganizational systems. Electronic Commerce Research and Applications, 10(1): 85-93.

Landeta J., 2006. Current validity of the Delphi method in social sciences. Technological Forecasting and Social Change, 73(5): 467-482.

Laudon K.C. and Laudon J.P., 2009. Management information systems: Managing the digital firm. New Jersey: Prentice Hall.

Linke A. and Zerfass A., 2012. Future trends in social media use for strategic organisation communication: Result of a Delphi study. Public Communication Review, 2(2): 17-29.

Linstone H.A. and Turoff M., 1975. The Delphi method: Techniques and applications. London: Addison-Wesley.

López E.I., Arcas N. and Alcón F., 2014. Uso y calidad de los sitios Web: evaluación en las empresas agroalimentarias murcianas. Revista española de estudios agrosociales y pesqueros, 237: 155-179.

Luna P., Infante A. and Martínez F.J., 2006. Los Delphi como fundamento metodológico predictivo para la investigación en sistemas de información y tecnologías de la información (IS/IT). Píxel-Bit. Revista de Medios y Educación, 26: 89-112.

MAGRAMA (Ministerio de Agricultura, Alimentación y Medio Ambiente), 2012. Estudio de la cadena de valor y formación de precios del sector del aceite de oliva. Campaña 2009-2010. Madrid: Gobierno de España.

MAGRAMA (Ministerio de Agricultura, Alimentación y Medio Ambiente), 2013. Lineas Estratégicas para la Internacionalización del Sector Agroalimentario. Madrid: Gobierno de España.

Malla F.G. and Zabala I., 1978. Previsión del futuro en la empresa: el método Delphi. Estudios Empresariales, 39: 13-24.

Medina M.J., Bernal E., Mozas A., Moral E. and Fernández D., 2016. Efficiency of organic farming companies that operate in an online environment. Custose@gronegocio, 11(4): 264-289.

Mohedano F.O., 2013. El método Delphi, prospectiva en Ciencias Sociales a través del análisis de un caso práctico. Revista EAN, 64: 31-54.

Moral E., Bernal E., Mozas A. and Medina M.J., 2014. Internacionalización del sector oleícola gi- ennense. Mercados electrónicos. Jaén: Instituto de Estudios Giennenses.

Mozas A., Bernal E., Medina M.J. and Fernández D., 2015. El cooperativismo agroalimentario en Andalucía. Retos y oportunidades. In: IECA: Información Estadística y Cartográfica de Andalucía. Consejería de Economía, Innovación, Ciencia y Empleo, 185-194.

Mozas A., Bernal E., Fernández D. and Medina M.J., 2016a. Web quality as a determining factor in the online retailing of organic products in Spain. New Medit, 2: 28-36.

Mozas A., Bernal E., Medina M.J. and Fernández D., 2016b. Factors for success in online social networks: An fsQCA approach. Journal of Business Research, 69: 5261-5264.

Mozas A. and Bernal E., 2012. Posibilidades y aplicaciones de la Web 2.0: un caso de estudio aplicado a la economía social. CIRIEC-España, Revista de Economía Pública, Social y Cooperativa, 74: 261283.

Okoli C. and Pawlowski S.D., 2004. The Delphi method as a research tool: an example, design considerations and applications. Information and Management, 42(1): 15-29.

Parras M., Torres F.J. and Mozas A., 2013. El comportamiento comercial del cooperativismo oleícola en la cadena de valor de los aceites de oliva en España. In: Briz J., De Felipe I. Metodología y funcionamiento de la cadena de valor agroalimentaria. Editorial Agrícola Española, 497-517.

Perkins M. and Witt L., 1961. Capital Formation: Past and Present. Journal of Farm Economics, 43(2): 333-343.

Pomareda C. 2001. Tecnología, competitividad y desarrollo en la agricultura de Centroamérica. Costa Rica: IICA.

Rasheed H.S., 2005. Foreign entry mode and performance: the moderating effects of environment. Journal of Small Business Management, 43(1): 4151.

Rita L. and Sunny W.H., 2012. How companies cultivate relationships with publics on social network sites: Evidence from China and the United States. Public Relations Review, 38(5): 723-730.

Romero A.B. and Cànoves G., 2005. Las tecnologías de la información y la comunicación en el desarrollo del turismo rural. Documents d'anàlisi geogràfica, 46: 105-117.

Rowe G. and Wright G., 1999. The Delphi technique as a forecasting tool: Issues and analysis. International Journal of Forecasting, 15(4): 353-375. 
Sadowski B.M., Maitland C. and Van Dongen J., 2002. Strategic use of the Internet by small and medium sized companies: an exploratory study. Information Economics and Policy, 14: 75-93.

Sanz J., Hervás I., Sánchez F. and Coq D., 2011. Investigación e innovación en el sector del aceite de oliva en España. Problemas, oportunidades y prioridades de $I+D+i$. Programa Nacional de Redes del Plan Nacional de I+D+i: ALENTA. Plataforma Tecnológica del Olivar.

Sayadi S., Ruíz P. and Vázquez A., 2012. Prioridades de I+D en el sistema agroalimentario andaluz. Especial referencia a su complejo olivarero-oleícola. Revista Española de Estudios Agrosociales y Pesqueros, 233: 129-178.

Shejtman A. and Berdegué J., 2004. Desarrollo territorial rural. Debates y temas rurales, 1: 7-46.
Stansfield M. and Grant K., 2003. An investigation into issues influencing the use of the Internet and electronic commerce among small-medium sized enterprises. Journal of Electronic Commerce Research, 4(1): 15-33.

Vega M., Parras M., Torres F.J. and Murgado E.M., 2011. Factores impulsadores e inhibidores del consumo de alimentos ecológicas en España. El caso del aceite de oliva. Interciencia, 36(3): 178-184.

Von Der Gracht H.A., 2012. Consensus measurement in Delphi studies. Review and implications for future quality assurance. Technological Forecasting and Social Change, 79(8): 1525-1536.

Wei C., Zhang C. and Sutanto J., 2013. The influence of user interaction and participation in social on the consumption intention of niche products. Information and Management, 50: 661-672. 